Mara Tieken is the recipient of the 2016 Ernest A. Lynton Award for the Scholarship of Engagement for Early Career Faculty. The award recognizes exemplary community-engaged scholarly work across faculty roles. The scholarship of engagement represents an integrated view of faculty roles in which teaching, research/creative activity, and service overlap and are mutually reinforcing, is characterized by scholarly work tied to a faculty member's academic expertise, is of benefit to the external community, is visible and shared with community stakeholders, and reflects the mission of the institution. Community engagement is defined by relationships between those in the university and those outside the university that are grounded in the qualities of reciprocity, mutual respect, shared authority, and co-creation of goals and outcomes. Such relationships are by their very nature trans-disciplinary (knowledge transcending the disciplines and the college or university) and asset-based (where the strengths, skills, and knowledges of those in the community are validated and legitimized).

Dr. Tieken was selected from an outstanding pool of finalists because her work exemplifies the award's criteria. She approached her work with rural schools by validating the knowledge assets in the communities she worked with. Dr. Tieken undertook research that addressed social and racial justice and equity in those communities. She brought her students into a pedagogy shaped by participatory epistemology in which they and the community partners they work with are knowledge producers and active participants in building a wider public culture of democracy. And through integrating her faculty roles, Dr. Tieken contributed significant service with the partners she worked with. Further, she is an agent for change on her own campus, working to create an institutional environment that supports community engaged scholars.

Dr. Tieken's emergence as an engaged scholar highlights the critical nature of deep relationships with community partners, the importance of making engagement part of the socialization and training in graduate education, the significance of mentors, and the ways that institutions of higher education cultivate scholarly innovation by attending to the kinds of commitments and structures that support, recognize, and reward community engaged scholarship. As an engaged scholar, she pursues community engagement to advance knowledge that can address global social issues as they are manifest locally, and as perhaps the best way to advance knowledge in ways that fulfill the democratic purposes of higher education.

The Lynton Award is the only national faculty award for the scholarship of engagement. 2017 marks the $20^{\text {th }}$ anniversary of the Lynton Award; it has been hosted since 1997 by the New England Resource Center for Higher Education at the University of Massachusetts, Boston. Starting in 2017, the Lynton Award is sponsored by the Swearer Center at Brown University in partnership with the Coalition of Urban and Metropolitan Universities (CUMU). 


\section{The Evolution of a Community-Engaged Scholar}

Mara C. Tieken

\section{Introduction}

I began my work in education as a rural teacher: I taught first on a remote island in the Pacific, and then in a fifth grade classroom in rural Vermont, and finally as a third grade teacher in the hills of Tennessee. These were very different places and very different schools, with different demographics and geographies and economies and politics. Yet, in all of them, I learned one thing again and again: these schools were vitally important to these rural communities. They shaped the communities' children, of course, but they also shaped their social interactions, their political power, their economic prospects, their racial dynamics, their futures (Tieken, 2014). People, both young and old, gathered at the schools and wrestled with school policy; they formed friendships and traversed racial boundaries; they debated school dress codes and determined curricular content. And, together, through crowded Friday-night gymnasiums and long lines at fundraiser suppers and emotion-filled school board meetings, they argued for their continued existence.

But these vitally important rural schools were often overlooked. Despite constituting a third of all public schools nationwide (Johnson, Showalter, Klein, \& Lester, 2014), rural schools are largely absent from discussions about policymaking and practice (Isserman, 2007; Schafft, 2016): researchers and lawmakers focus on urban and suburban schooling. This absence is conspicuous and, as many rural communities fight academic sanctions or consolidation policies to simply hold onto their schools (Howley, Johnson, \& Petrie, 2011; Tieken, 2014), consequential. I wanted to help fill this gap, and so I left teaching for graduate school, hoping to keep one foot in rural communities - to remain engaged with rural communities - while also entering the world of academia and policymaking, to produce research and policies that reflected and responded to rural contexts.

And this is, mostly, what I now do: I collaborate with rural schools, communities, and organizations in efforts to further educational equity across geographic, racial, and class boundaries. As such, my work is representative of a broader kind of scholarship generally known as community-engaged scholarship (CES), in which researchers collaborate with community partners to challenge the economic, political, and social structures that produce inequality (Others use different names for these kinds of collaborations, including community-based research, publicly engaged scholarship, action research, and participatory action research). These collaborations vary in format and methods but are similar in their intent to generate knowledge relevant to social change agendas (Strand, Marullo, Cutforth, Stoecker, \& Donohue, 2003).

The demand for this kind of community-engaged research is unmistakable, as scholars and practitioners increasingly call for research that actively engages communities (Boyer, 1990, 1996; Ladson-Billings \& Tate, 2006; Strand et al., 2003; Tierney, 2013). There is a growing understanding that our society's most pressing problems - widening income inequality, persistent educational disparities, inequities in access to health care, racially disproportionate 
police practices - will only be addressed through research and practice with the communities who feel these injustices most acutely. Colleges and universities can no longer survive as "isolated islands," argued Ernest Boyer, past president of the Carnegie Foundation; instead, they must take on the responsibility of "our most pressing social, civic, and ethical problems" and become "staging grounds for action" (Boyer, 1996, p. 21).

Yet, despite the urgency of these calls, many argue that higher education has not yet fully embraced its civic mission (Saltmarsh \& Hartley, 2011). This failure can be seen in the challenges that continue to compromise the training and early careers of community-engaged scholars; without greater support for the development of scholars with the skills and values of community-engaged work, our ability to address these urgent social issues will remain limited. In this reflection, I share my own storyof how community engagement has grown increasingly important to my work and identity.I hope to show the evolution of a community-engaged scholar, focusing on three supports that helped nurture this shift: a strong community-engaged doctoral training, ideological and material resources, and an early-career opportunity for reflection and recognition.

\section{Learning values: community-engaged doctoral training}

I left rural Tennessee and arrived at the doctoral program of the Harvard Graduate School of Education with a specific set of beliefs, motivations, and values: I felt that rural schools were essential to rural communities, that they were often disregarded by policymakers and researchers, and that this omission threatened the sustainability of rural communities. Understanding rural schools and communities, in all their strengths and challenges, their particularities and commonalities, and then using this understanding to inform more responsive policies was a matter of educational equity. However, the motivations and values that had sent me to graduate school often seemed unwelcome there. Most methods classes focused on "objectivity," "unbiased analysis," the documentation of flaws and weaknesses - and I was just too close to rural places. I was urged to separate myself, and I was taught a new language that would give me some distance: communities were "subjects," their trust was "gaining entry," their words were "data for analysis." The structure of the academy seemed to reinforce these same power dynamics, with faculty as experts involving students in discrete parts of their various projects, all conducted at a safe remove from their "subjects."

I wasn't alone: most doctoral students are trained to conduct short-term, relatively detached research projects on, rather than with, communities (Strand et al., 2003). They are taught the superiority of academic knowledge over other forms and ways of knowing (Boyte \& Fretz, 2011). They can experience hierarchical relationships with faculty (Walker, Golde, Jones, Bueschel, \& Hutchins, 2008), which they often replicate with participants. And they typically learn that a researcher's role is to be critical, to focus on defects and failings (LawrenceLightfoot \& Davis, 1997). Many students feel forced to abandon their core civic values; others grow disillusioned with academia (Stanton \& Wagner, 2006), and many never finish (Walker et al., 2008).

But I was lucky. Two of my professors, Mark Warren and Karen Mapp, were beginning a research project that had two goals: to produce a series of case studies analyzing the work of communities organizing for education reform, while also developing and supporting a new 
generation of community-engaged scholars. The project attracted a diverse group of doctoral students, with different professional backgrounds and racial identities and home communities, bound together by a shared value for social justice and a growing alienation from academia. Over the next five years, we worked closely with six groups organizing for education reform to craft research questions, draft interview protocols, collect data, develop our analysis, and write and rewrite - all of which, for me, meant long periods of time back in the rural South, collaborating with a site organizing communities across the Mississippi Delta. This work produced a number of books and articles, including A match on dry grass: Community organizing as a catalyst for school reform (Oxford University Press, 2011), and several public presentations, opportunities and publications that developed the field of education organizing and promoted these groups' work. And, among the project's fifteen students, the project also developed the skills and dispositions of CES: we learned how to build "horizontal" and collaborative research relationships, we grew fluent in articulating our values and telling the stories of how we came to this work, and we began to interrogate our positionalities as researchers by embracing diversity in background, perspective, and experience (Warren, Park, \& Tieken, 2016). It was challenging work to negotiate boundaries that come with the privileged position of researcher as well as to open oneself to honest self-assessment and critical feedback. But, through this work, we discovered that research could be a tool for social justice.

\section{Finding a path: Structural and ideological supports}

As I finished graduate school, I accepted a tenure track position in the education department at Bates College, a small, highly selective liberal arts college in Lewiston, Maine. The position was a good fit for me, with a focus on teaching, generous support for research, and a location in a very rural state. Bates also has a strong tradition of community-engaged work. The college's mission is, in part, to develop students' capacities for "informed civic action" and "responsible stewardship of the wider world," and a rich network of partnerships link the college to the local community. In the education department, all classes have a community-engaged component; students work in classrooms or with nonprofits to provide tutoring, mentoring, and research. This fieldwork is facilitated by the college's Harward Center for Community Partnerships, which supports faculty in developing community-engaged classes or research projects.

During my job search, this orientation toward community engagement was not a characteristic I sought out; despite my strong doctoral CES training, I still tended to think of "research" and "teaching" as endeavors relatively disconnected from "community," a problematic yet irreconcilable divide that was, ultimately, an inevitable characteristic of academic work. But after five-and-a-half years at Bates, I have found that my work has grown more genuinely and consistently community-engaged, and so has my identity. My research is more responsive, more tied to questions generated in or with rural communities, more directly relevant to their organizing and development and policy work. I am better able to find ways of making my research useful, whether as an organizing tool (winning a waiver to Arkansas's consolidation law) or through material profits (using royalties to support local schools and community organizations.) My relationships with partners are deeper and richer, and collaborations in one area, such as supporting the organizing work of Pittsfield Listens in New Hampshire, lead to collaborations in others, such as working with my School Reform class to design a college 
informational session and campus visit for Pittsfield Listens youth. I am more comfortable changing a project's direction based on feedback: a long drive across the Arkansas Delta with a long-time partner convinced me that school closures, not school segregation, was the most direct and immediate threat to the sustainability of rural black communities, leading to shifting a research project to focus on these closures. My classes are more creative in their approach to fieldwork; my research methods class partners with a local community organization to collect data needed for program improvement and grant-writing - and wrestle with hard questions about communicating findings openly and respectfully. And this work feels more grounded, more closely tied to the values that once sent me to graduate school.

This development in my work wouldn't have happened at an institution without a commitment to community-engaged work or the infrastructure to support it. The Harward Center handles the logistics of community-engaged work, finding my students course-relevant placements for their fieldwork, and I can turn to their staff with an idea for a project,like creating a seminar on community-engaged, qualitative research methods. They in turn can help me find interested community partners with needs to fill. Bates is also known throughout the state for its engagement, and I frequently field calls and queries from Maine schools and nonprofits, often leading to productive research, teaching, and learning partnerships. Continued opportunities to collaborate with students and community members have led to more consistent, intensive partnerships. Today, the occasional, less engaged, more traditional research project or class feels somewhat irrelevant and inauthentic to the schools and communities I do work with.

But, that said, this work still has its challenges. Many are common across CES, such as its timeintensiveness or the disconnect between the academic reward system, which credits publishing in top-tier journals, and partners' needs and goals, which typically require a very different method of dissemination (O'Meara, 2011). Others are more tied to Bates's small, liberal arts college context, including an intensive teaching load, considerable campus service expectations, few colleagues with related research interests, and no opportunities for collaboration with graduate students. And some relate to the rural nature of my work. Historically, policy and reform have happened to rural communities, not with them, and many are often understandably distrustful of outsiders; collaborative relationships, therefore, often require even more time and work. For much of the broader public, rural schools do not hold the same appeal as urban schools, making it difficult to generate funder support or student interest. And Bates is located in a city, and rural communities are, by definition, often at quite a distance; these relationships are travel-intensive, and the distance can prohibit involving students.

\section{Reflection and recognition: an early-career award}

Making my case for tenure this fall presented new obstacles, mostly around communicating the meaning and worth of community-engaged work. I struggled to find outside reviewers that understood this approach. And even within my institution, one with an expressed commitment to community engagement, most faculty take a more traditional approach to research and teaching, and I worried whether they will see the value in pursuing questions of importance to community partners, rather than ones dictated by other researchers. I also had to wrestle with the format for presenting my case, which requires separate statements on research, teaching, and service. My 
work spans these categories, and dividing it as required seemed to undermine its richness and purpose. And so, like many community-engaged tenure candidates, I faced an audience unfamiliar with this approach and a process ill-suited to educate them (O'Meara, 2011) — at a moment that will shape the rest of my professional career.

At the same time that I was gathering my tenure materials, I was nominated by the director of the Harward Center, Darby Ray, for the Ernest A. Lynton Award for the Scholarship of Engagement for Early Career Faculty, awarded for connecting teaching and research to community engagement and involving communities in "public problem-solving." To be nominated was gratifying but also daunting, for with the nomination came a lengthy application — a process that, when coupled with my tenure case, seemed overwhelming. But I soon found that pulling together the Lynton Award application was an experience wholly different from the tenure process, one that offered space for self-reflection and a connection to the field of CES. In asking me to rationalize my community-engaged approach, the application was an opportunity to share my "story of self" as a community-engaged scholar,to identify, explore, and explain the path that has taken me from teaching in rural K-12 classrooms to teaching, research, and partnership at a small college in Maine and beyond. The application required a compilation of supporting letters from colleagues, students, and partners that testified to the horizontal, collaborative relationships I have developed, and its questions entailed an interrogation of my perspectives and values as a researcher. Applying for the Lynton Award both affirmed and strengthened many of the skills I developed in my doctoral work; whereas my tenure case required justifying the messy interconnectedness of my work, this application expected and celebrated it.

Shortly before submitting my tenure materials this fall, I learned that I would receive the Lynton Award. It was a surprising, humbling honor. I am joining a remarkable, interdisciplinary group of recipients that have found creative methods to use their teaching and research to further issues of social and racial justice. This honor is also a gratifying recognition of rural work and the efforts of a vast network of teachers, students, organizers, and residents in rural communities across Arkansas, Maine, and beyond. This is an important distinction, as much recent CES has taken place in and around urban communities.

\section{Becoming a community-engaged scholar}

I didn't begin this work as a community-engaged scholar. Rather, I began as a teacher, one that wanted to remain connected to the people and places she loved. I came to community engagement as a method of academic practice during my doctoral training, when I was disillusioned with traditional academic approaches to research and teaching. Though this strong doctoral training allowed me to begin to understand research as a tool in the struggle for educational justice, I still didn't see myself as a community-engaged scholar. It is only now, after another five years of doing this work that I have come to identify in this way. For me, then, this identity evolved, and its evolution was nurtured by three key supports. Without a strong community-engaged doctoral training, I don't think I would be an academic. This training showed me that research can be a tool for furthering educational equity. Bates's structural and ideological supports emerged from the school's long history of community engagement, the education department's norm of community-engaged teaching, and the Harward Center's 
assistance in arranging student placements and brokering community relationships. All these created an expectation of community-engaged teaching and set a foundation for my work to grow more engaged, to continue to blur the boundaries separating research from teaching, teaching from learning, and campus from community. A more recent support is the early-career award. The Lynton application was an opportunity to explore this emerging community-engaged identity, articulate my values and connect them to my practice, and assess my skills and identify areas for growth; receiving the award is an affirmation of a newly comfortable identity.

Together, these resources have enabled me to commit and connect to Bates's surrounding city and, importantly, to continue to work with rural communities, exploring questions important to these rural places and their schools, sharing resources useful to their struggle for recognition and equity, and communicating their challenges, strengths, and experiences to others. It's a very imperfect practice, and I am grateful to partners willing to open themselves to these complicated relationships, students eager to consider sticky questions of ethical research and teaching, and collaborators ready to tell me when I'm wrong. As I contemplate the next phase of my career, I anticipate new questions to explore and challenges to wrestle with: how does place - and, specifically, rurality - matter in community-engaged work? How will I continue this work through the next stage of my career, when I encounter new demands on my time and capacity? What will be my role in supporting and sustaining a new generation of community-engaged scholars? And if I get tenure, how will I negotiate its responsibilities, particularly the paradox of benefitting from an extraordinary privilege while also working to dismantle systems of privilege and inequality?

I was lucky to enjoy the support of strong doctoral training, a wealth of institutional resources, and the opportunity to articulate and share my story; many doctoral students and early career scholars do not, and this absence threatens to keep academia removed from communities and, therefore, unable to address important issues of educational equity and geographic justice. But there's nothing inevitable or necessary about this divide. With the right supports, we can live in both of these worlds. ${ }^{1}$

\section{References}

Boyer, E. L. (1990). Scholarship reconsidered: Priorities of the professorate. Princeton, NJ: Carnegie Foundation for the Advancement of Teaching.

Boyer, E. L. (1996). The scholarship of engagement. Journal of Public Service and Outreach, 1(1), 11-21. https://dx.doi.org/10.2307/3824459

Boyte, H. C., \& Fretz, E. (2011). Civic professionalism. In J. Saltmarsh \& M. Hartley (Eds.), "To serve a larger purpose": Engagement for democracy and the transformation of higher education (pp. 82-101). Philadelphia: Temple University Press.

\footnotetext{
${ }^{1}$ Shortly before publication, Mara learned that she would be granted tenure.
} 
Howley, C., Johnson, J., \& Petrie, J. (2011). Consolidation of schools and districts: What the research says and what it means. Retrieved from Boulder, CO:

Isserman, A. M. (2007). Getting state rural policy right: Definitions, growth, and program eligibility. The Journal of Regional Analysis and Policy, 37(1), 72-79.

Johnson, J., Showalter, D., Klein, R., \& Lester, C. (2014). Why rural matters 2013-14: The condition of rural education in the 50 states. Retrieved from Washington, DC:

Ladson-Billings, G., \& Tate, W. F. (Eds.). (2006). Education research in the public interest: Social justice, action, and policy. New York: Teachers College Press.

Lawrence-Lightfoot, S., \& Davis, J. H. (1997). The art and science of portraiture. San Francisco: Jossey-Bass Publishers.

O'Meara, K. (2011). Faculty civic engagement: New training, assumptions, and markets needed for the engaged American scholar. In J. Saltmarsh \& M. Hartley (Eds.), "To serve a larger purpose": Engagement for democracy and the transformation of higher education (pp. 177-198). Philadelphia: Temple University Press.

Saltmarsh, J., \& Hartley, M. (2011). "To serve a larger purpose". In J. Saltmarsh \& M. Hartley (Eds.), "To serve a larger purpose": Engagement for democracy and the transformation of higher education (pp. 1-13). Philadelphia: Temple University Press.

Schafft, K. A. (2016). Rural education as rural development: Understanding the rural schoolcommunity well-being linkage in a 21st century policy context. Peabody Journal of Education, 91(2), 137-154. https://dx.doi.org/10.1080/0161956X.2016.1151734

Stanton, T. K., \& Wagner, J. (2006). Educating for democratic citizenship: Renewing the civic mission of graduate and professional education at research universities. Stanford, CA: California Campus Compact.

Strand, K., Marullo, S., Cutforth, N., Stoecker, R., \& Donohue, P. (Eds.). (2003). Communitybased research and higher education: Principles and practices. San Francisco: JosseyBass.

Tieken, M. C. (2014). Why rural schools matter. Chapel Hill: University of North Carolina Press.

Tierney, W. G. (2013). Beyond the ivory tower: The role of the intellectual in eliminating poverty. Educational Researcher, 42(6), 295-303.

https://dx.doi.org/10.3102/0013189X13502772

Walker, G. E., Golde, C. M., Jones, L., Bueschel, A. C., \& Hutchins, P. (2008). The formation of scholars: Rethinking doctoral education for the twenty-first century. San Francisco: Jossey-Bass. 
Warren, M. R., Park, S. O., \& Tieken, M. C. (2016). The formation of community-engaged scholars: A collaborative approach to doctoral training and education research. Harvard Educational Review, 86(2), 233-260. https://dx.doi.org/10.17763/0017-8055.86.2.233 


\section{Author Information}

Mara Casey Tieken is an assistant professor of education at Bates College. A former third-grade teacher in rural Tennessee, she studies racial and educational equity in rural schools and communities. She collaborates with schools and organizations throughout the rural South and Northeast to foster better understandings of rural school/community relationships, rural college access, and rural community organizing and to promote educational justice across lines of race, class, and geography. At Bates, Mara teaches classes on school reform and racial equity; through fieldwork, her students partner with teachers, administrators, and youth organizations to expand educational opportunity in Lewiston, Maine, and beyond.

Mara C. Tieken

Assistant Professor

Education Department

Bates College

Pettengill Hall, Room 304

Lewiston, Maine 04240

E-mail: mtieken@bates.edu

Telephone: 207-786-6064 